\title{
Efficacy of florfenicol for control of mortality associated with Flavobacterium columnare in tilapia
}

\author{
Thinh H. Nguyen*, \& Hue N. D. Truyen \\ Faculty of Fisheries, Nong Lam University, Ho Chi Minh City, Vietnam
}

\begin{abstract}
ARTICLE INFO
Research paper

Received: November 11, 2017

Revised: January 15, 2018

Accepted: January 22, 2018
\end{abstract}

\section{Keywords}

Flavobacterium columnare

Florfenicol

Tilapia

\section{* Corresponding author}

Nguyen Huu Thinh

Email: nhthinh@hcmuaf.edu.vn

\begin{abstract}
The efficacy of florfenicol for control of mortality associated with Flavobacterium columnare was studied in tilapia. F. columnare T3-8/10 strain used for infection was tested for virulence by bath challenge to tilapia (body weight: BW 14 - $16 \mathrm{~g}$ ) and antimicrobial sensitivity test. The results showed $\mathrm{LD}_{50}$ of this bacterial strain was $4.8 \times 10^{4} \mathrm{CFU} / \mathrm{mL}$ and it was sensitive to florfenicol. Experiment for control mortality caused by the bacterium in tilapia (BW $18-20 \mathrm{~g}$ ) was designed with four treatments including negative control (unifected fish), positive control, NT10 and NT15 (infected with $\mathrm{LD}_{50}$ ). Just after infection, fish in positive control, NT10 and NT15 treatments were treated with florfenicol at doses of 0,10 and $15 \mathrm{mg} / \mathrm{kg} \mathrm{BW} /$ day for 10 days, respectively, by feeding fish with medicated feed. Mortality of fish in positive control treatment after 14 days of infection was $54.0 \pm 5.47 \%$ and statistically different in comparison with those in negative control, NT10 and NT15 treatments were $0.0,3.0 \pm 4.72$ and $2.60 \pm 2.51 \%$, respectively $(P<0.05)$. Fish in NT10 and NT15 treatments were sampled for testing florfenicol residue in the flesh at day 1,16 , 20 and 24 after treatment. The results showed florfenicol residue levels in the flesh of sampled fish at all testing timepoints were significantly lower in comparision with the safe concentration lower than $1000 \mathrm{ppb}$ regulated by the Ministry of Agriculture and Rural Development of Vietnam.
\end{abstract}

Cited as: Nguyen, T. H., \& Truyen, H. N. D. (2018). Efficacy of florfenicol for control of mortality associated with Flavobacterium columnare in tilapia. The Journal of Agriculture and Development 17(4), 76-85. 


\title{
Đánh giá hiệu quả kiểm soát tỷ lệ chết trên cá rô phi nhiễm Flavobacterium columnare bằng florfenicol
}

\author{
Nguyễn Hữu Thịnh \& Truyện Nhã Định Huệ
}

Khoa Thủy Sản, Trường Đại Học Nông Lâm TP. Hồ Chí Minh, TP. Hồ Chí Minh

\author{
THÔNG TIN BÀI BÁO \\ Bài báo khoa học \\ Ngày nhận: 11/11/2017 \\ Ngày chỉnh sửa: 15/01/2018 \\ Ngày chấp nhận: 22/01/2018 \\ Từ khóa \\ Cá rô phi \\ Flavobacterium columnare \\ Florfenicol \\ Tác giả liên hệ \\ Nguyễn Hữu Thịnh \\ Email: nhthinh@hcmuaf.edu.vn
}

\section{TÓM TẮT}

Nghiên cứu hiệu quả của florfenicol trong kiểm soát tỷ lệ chết do Flavobacterium columnare được thực hiện trên cá rô phi. Chủng $F$. columnare T3-8/10 sử dụng cảm nhiễm cá với liều gây chết $\mathrm{LD}_{50}$ cá rô phi thí nghiệm $(14-16 \mathrm{~g} / \mathrm{cá})$ bằng phương pháp tắm là $4,8 \times 10^{4}$ $\mathrm{CFU} / \mathrm{mL}$ và nhạy cảm với florfenicol. Thí nghiệm kiểm soát bệnh do F. columnare trên cá $(18-20 \mathrm{~g} /$ cá $)$ có bốn nghiệm thức gồm đối chứng âm ĐC(-) không gây nhiễm; đối chứng dương $\mathrm{ĐC}(+)$, NT10 và NT15 gây nhiễm với liều $\mathrm{LD}_{50}$. Ngay sau khi gây nhiễm, cá ở ĐC $(+), \mathrm{NT10}$ và $\mathrm{NT} 15$ được cấp florfenicol với liều tương ứng 0,10 và $15 \mathrm{mg} / \mathrm{kg}$ thể trọng cá/ngày trong 10 ngày qua việc cho cá ăn thức ăn trộn sẵn kháng sinh. Tỷ lệ cá chết sau 14 ngày gây nhiễm ở $\mathrm{DC}(+)$ lên đến 54,0 $\pm 5,47 \%$ và khác biệt có ý nghĩa thống kê so với tỷ lệ chết ở ĐC(-), NT10 và NT15 lần lượt là $0,0,3,0 \pm 4,72$ và $2,60 \pm 2,51 \%(P<0,05)$. Cá ở NT10 và NT15 được thu mẫu kiểm tra dư lượng florfenicol trong cơ thịt vào các ngày $1,16,20$ và 24 sau khi ngưng cấp florfenicol. Dư lượng florfenicol trong cơ thịt cá ở tất cả các thời điểm thu mẫu đều thấp hơn rất nhiều so với mức 1000 ppb quy định bởi Bộ Nông Nghiệp và Phát Triển Nông Thôn Việt Nam.

\section{1. Đặt Vấn Đề}

Bệnh do Flavobacterium columnare đã xảy ra ít nhất trên 36 loài cá nuôi khắp thế giới, bao gồm nhiều loài cá nuôi có giá trị kinh tế quan trọng như cá da trơn Mỹ, cá hồi vân, cá tra và cá rô phi (Edward, 2000). Tại Việt Nam, bệnh do $F$. columnare cũng xảy ra và gây tổn thất lớn cho nghề nuôi cá tra thâm canh (Tu \& ctv. 2012). Bệnh này cũng đã ảnh hưởng nghiêm trọng trên cá rô phi nuôi. Cá tra, rô phi thường bị hao hụt rất lớn sau khi cá bị xây xát do vận chuyển hoặc do thay đổi điều kiện môi trường dột ngột do cơn mưa lớn và kéo dài. Khi nhiễm bệnh này, cá chết nhanh trong thời gian từ $2-4$ ngày sau khi có biểu hiện bệnh lý. Tỉ lệ cá chết khoảng 80 - 100\% đối với cá ương trong bể và $35-60 \%$ nuôi ở ao đất (Tu \& ctv., 2012).

Florfenicol là kháng sinh phổ rộng có thể dùng trong điều trị và làm giảm tỉ lệ chết do nhiều loại bệnh trên cá như bệnh viêm ruột và nhiễm trùng huyết trên cá da trơn Mỹ do Edwardsiella ictaluri (McGinnis \& ctv., 2003), bệnh nhiễm trùng máu Streptococcus iniae, bệnh thối mang, mòn đuôi trên cá rô phi do $F$. columnare (Gaunt \& ctv., 2010). Florfenicol đã được các nghiên cứu sử dụng ở liều 10 và $15 \mathrm{mg}$ florfenicol $/ \mathrm{kg}$ thể trọng cá/ngày với liệu trình điều trị trong 10 ngày. Kháng sinh này được phép sử dụng trong trị các bệnh nhiễm khuẩn cho cá nuôi tại 25 nước trên thế giới kể cả Mỹ (Gaunt \& ctv., 2010). Tại Việt Nam, florfenicol được cho phép sử dụng hạn chế với dư lượng trong cơ thịt cá sau khi thu hoạch ở mức thấp hơn 1000 ppb (Danh mục hóa chất kháng sinh hạn chế sử dụng trong sản xuất kinh doanh thủy sản, thông tư số 15/2009/TTBNN ngày 17 tháng 3 năm 2009 của Bộ trưởng Bộ Nông Nghiệp và Phát Triển Nông Thôn).

Cá rô phi có sản lượng nuôi ước đạt 200 ngàn tấn/năm tại Việt nam. Cá được nuôi chủ yếu trong lồng, bè trên sông. Hình thức nuôi này có hạn chế lớn nhất là khả năng kiểm soát bệnh do sự lây lan tự do của mầm bệnh trong nước sông và bè nuôi. Thêm vào đó, việc áp dụng trực tiếp các chất sát khuẩn vào nước trong bè nuôi như treo túi thuốc trong bè hay tạt trực tiếp vào bè thường không có hiệu quả phòng trị bệnh cao do không thể duy trì được nồng độ hóa chất trong 
nước trong thời gian đủ dài cho việc sát khuẩn. Do hạn chế trên nên việc trị bệnh cho cá nuôi bè chủ yếu vẫn được áp dụng qua đường tiêu hóa, cụ thể là biện pháp tẩm thuốc vào thức ăn cho cá ăn.

Nghiên cứu hiệu quả của florfenicol trong kiểm soát tỷ lệ chết trên cá rô phi nuôi nhiễm $F$. columnare là yêu cầu cấp thiết nhằm hạn chế được tác hại của bệnh và nâng cao tỷ lệ sống trong khi chưa có biện pháp phòng bệnh hiệu quả. Mục tiêu của nghiên cứu nhằm đánh giá hiệu quả của florfenicol với các liều cấp thuốc qua đường tiêu hóa trong kiểm soát tỷ lệ chết của cá rô phi nhiễm $F$. columnare trong điều kiện phòng thí nghiệm.

\section{Vật Liệu và Phương Pháp Nghiên Cứu}

\subsection{Vi khuẩn Flavobacterium columnare}

Chủng Flavobacterium columnare T3-8/10 phân lập từ cá rô phi bị bệnh mòn vây cụt đuôi vào năm 2016 lưu giữ tại phòng thí nghiệm Bệnh Học Thủy Sản, Trường Đại Học Nông Lâm được sử dụng trong nghiên cứu này. Chủng vi khuẩn này đã được định danh bằng đặc điểm hình thái, sinh hóa và sinh học phân tử. Vi khuẩn từ ống giống gốc được cấy trên Cytophaga agar (CA), ủ ở $28^{0} \mathrm{C}$ trong 72 giờ. Khuẩn lạc đặc trưng của vi khuẩn có màu vàng nhạt dạng rễ cây, dính chặt vào mặt thạch được tăng sinh trong $\mathrm{Cy}$ tophaga Broth (CB) ở nhiệt độ phòng trong 48 giờ trên máy lắc ngang với tốc độ 100 lần/phút. Canh khuẩn này được sử dụng cho thí nghiệm cảm nhiễm.

\subsection{Phân lập và định danh Flavobacterium columnare}

Cá bệnh từ các thí nghiệm cảm nhiễm được thu mẫu kiểm tra sự cảm nhiễm vi khuẩn tại các vết loét trên da và vây bị mòn. Nhớt da tại các vị trí này được soi tươi và nhuộm gram, quan sát hình thái dưới kính hiển vi. Mẫu cấy ria mẫu nhớt từ các vết thương được thực hiện trên môi trường chọn lọc $\mathrm{CA}$ bổ sung polymyxin $\mathrm{B} 10 \mathrm{IU} / \mathrm{mL}$ và neomycin $10 \mu \mathrm{g} / \mathrm{mL}$ (Sigma-Aldrich). Các đĩa cấy phân lập được ủ ở $28^{\circ} \mathrm{C}$ trong 72 giờ. Sau đó, vi khuẩn được cấy thuần bằng cách chọn những khuẩn lạc đặc trưng, đứng riêng lẻ cấy ria lên môi trường $\mathrm{CA}$ mới.

Các gốc vi khuẩn phân lập thuần được định danh bằng kỹ thuật Polymerase Chain Reaction (PCR). Kit NKALKLYS-DNAPREP của Công ty Trách Nhiệm Hữu Hạn Dịch Vụ Thương Mại Nam Khoa (công ty Nam Khoa) được sử dụng ly trích DNA từ vi khuẩn phân lập thuần. Khuẩn lạc vi khuẩn được cho vào ống eppendorf $1,5 \mu \mathrm{L}$ chứa $500 \mu \mathrm{L}$ dung dịch tách chiết, ủ ở $96^{0} \mathrm{C}$ trong 10 phút trong buồng ủ nhiệt khô, làm lạnh nhanh trong khay đá trong 10 phút, sau đó ly tâm ở $13.000 \mathrm{rpm}$ trong 5 phút. $10 \mu \mathrm{L}$ dịch nổi được pha loãng với $40 \mu \mathrm{L}$ TE $1 \mathrm{X}$, đánh khuấy trong 5 giây và sử dụng như mạch khuôn DNA cho phản ứng PCR.

Kỹ thuật PCR một bước được áp dụng để phát hiện Flavobacterium columnare. Cặp mồi FcFd (5'-TGCGGCTGGATCACCTCCTTTCTAGAGACA-3' và FcRs (5'-TAATYRCTAAAGATGTTCTTTCTACTTGTT TG-3' được sử dụng khuếch đại đoạn gen có kích thước 504 bp (Panangala \& ctv., 2007). Mồi được cung cấp từ công ty IDT (Mỹ) với nồng độ gốc là $100 \mu \mathrm{M}$ (100 pmoles $/ \mu \mathrm{L}$ ). Thành phần phản ứng $\mathrm{PCR}$ với thể tích $25 \mu \mathrm{L}$ gồm Gotag Green Master Mix 2X 12,5 $\mu \mathrm{L}$, mồi xuôi $\mathrm{FcFd}(20 \mu \mathrm{M}) 0,5 \mu \mathrm{L}$, mồi ngược FcRs $(20 \mu \mathrm{M}) 0,5 \mu \mathrm{L}$, nước không chứa DNA 9,5 $\mu \mathrm{L}$ và DNA ly trích $2 \mu \mathrm{L}$. Phản ứng khuếch đại được thực hiện trong máy luân nhiệt BioRad iQ5 với quy trình nhiệt gồm 1 chu kỳ kích hoạt polymerase $\left(95^{\circ} \mathrm{C}, 1^{\prime}\right), 30$ chu kỳ biến tính, bắt cặp và tổng hợp (theo thứ tự $95^{\circ} \mathrm{C}, 30$ giây; $63^{\circ} \mathrm{C}, 45$ giây và $72^{0} \mathrm{C}, 30$ giây) và cuối cùng 1 chu kỳ kéo dài mạch $\left(72^{\circ} \mathrm{C}, 10^{\prime}\right)$. Sản phẩm khuếch đại được điện di trên gel agarose $3 \%$.

\subsection{Xác định liều $\mathrm{LD}_{50}$}

Cá rô phi, trọng lượng 14 - 16 g/cá, được sử dụng trong các thí nghiệm cảm nhiễm. Trước khi thực hiện các thí nghiệm, năm cá thể cá được kiểm tra ngẫu nhiên tình trạng nhiễm ký sinh trên da và mang dưới kính hiển vi và nhiễm khuẩn bằng cách cấy mẫu gan, thận và lách trên môi trường Brain Heart Infusion agar. Sau đó, cá được đưa vào bể $75 \mathrm{~L}$ chứa $50 \mathrm{~L}$ nước trước khi gây nhiễm 7 ngày cho thích nghi với môi trường nước trong bề.

Môi trường $\mathrm{CB}$ đã tăng sinh chủng $F$. columnare T3-8/10 được điều chỉnh về mật độ quang OD 0,2 ở bước sóng $590 \mathrm{~nm}$ và xác định mật độ vi khuẩn bằng phương pháp cấy trang đếm số khuẩn lạc phát triển trên môi trường $\mathrm{CA}$ được sử dụng gây nhiễm cho cá.

Thí nghiệm được bố trí theo phương pháp hoàn toàn ngẫu nhiên với bốn nghiệm thức có các liều 
gây nhiễm chênh lệch nhau 10 lần (theo thứ tự từ thấp đến cao gồm nghiệm thức $\mathrm{T} 1, \mathrm{~T} 2, \mathrm{~T} 3$ và T4) và 1 nghiệm thức đối chứng (ĐC) không gây nhiễm. Cá được gây nhiễm bằng phương pháp tắm, mỗi nghiệm thức có 2 lần lặp lại với 20 cá/lần lặp lại. Sử dụng $500 \mathrm{~mL}$ canh $\mathrm{CB}$ đã được điều chỉnh $\mathrm{OD}$ vào bể nuôi cá chứa $49,5 \mathrm{~L}$ nước. Sau đó, lấy $5 \mathrm{~L}$ nước từ bể này chuyển sang bể thứ hai chứa $45 \mathrm{~L}$ nước. Tiếp tục làm như vậy cho đến bể thứ 4 . Nước trong bể của nghiệm thức đối chứng không chứa canh khuẩn gây bệnh.

Cá được cho ăn thức ăn Aquaxcel 7404 (Cargill) với mức $4 \%$ trọng lượng thân/ngày chia làm 2 lần $(8$ giờ và 16 giờ). Nước trong bể được sục khí liên tục và thay 20 - 30\% nước mỗi ngày. Nhiệt độ phòng gây bệnh được giữ ở mức $25^{0} \mathrm{C}$ bằng máy điều hòa nhiệt độ. Các bể thí nghiệm được chăm sóc như nhau. Các chỉ tiêu $\mathrm{NH}_{3}, \mathrm{pH}$ và oxy hòa tan $(\mathrm{DO})$ của nước trong bể được kiểm tra cách 3 ngày 1 lần vào lúc 8 giờ sáng bằng bộ kít Sera. Nhiệt độ được đo 2 lần/ngày $(8$ giờ và 16 giờ) bằng nhiệt kế rượu. Triệu chứng, bệnh tích của cá bệnh, số cá chết trong bể được ghi nhận ngày hai lần liên tục suốt 14 ngày sau gây nhiễm. Cá bệnh được thu mẫu cấy phân lập vi khuẩn và tiến hành định danh bằng kỹ thuật PCR xác định tác nhân gây chết đối với cá. Liều $\mathrm{LD}_{50}$ được xác định theo phương pháp của Reed \& Muench (1938).

\section{4. Đặc điểm nhạy kháng sinh của Flavobac- terium columnare}

Sáu loại đĩa kháng sinh gồm florfenicol $30 \mu \mathrm{g}$ (Oxoid), ampicillin $10 \mu \mathrm{g}$, doxycycline $30 \mu \mathrm{g}$, gentamycin $10 \mu \mathrm{g}$, tetracycline $30 \mu \mathrm{g}$ và trimethoprim-sulfamethoxazole $1,25 / 23,75 \mu \mathrm{g}$ (Công ty Nam Khoa) được sử dụng kiểm tra tính nhay cảm kháng sinh của chủng $F$. columnare T38/10. Thí nghiệm được thực hiện theo phương pháp Bauer - Kirbry với môi trường MuellerHinton Agar (Merck). Đường kính vòng vô khuẩn được ghi nhận sau 72 giờ ủ ở $28^{0} \mathrm{C}$. Tính nhạy cảm kháng sinh của vi khuẩn được xác định dựa vào hướng dẫn chuẩn đường kính của vòng vô khuẩn theo tài liệu McGinnis \& ctv. (2003).

\subsection{Sử dụng florfenicol kiểm soát bệnh}

Cá rô phi, trọng lượng 19 - 21 g/cá, được sử dụng trọng thí nghiệm này. Cách tăng sinh vi khuẩn, gây nhiễm và chăm sóc cá sau gây nhiễm cũng như phân lập định danh vi khuẩn xác định tác nhân gây bệnh được thực hiện tương tự như ở thí nghiệm xác định $\mathrm{LD}_{50}$.

Thức ăn Aquaxcel 7404 (Cargill) được nghiền và trộn với florfenicol (Virbac) ở hai mức 500 và $750 \mathrm{mg} / \mathrm{kg}$ thức ăn. Thức ăn đối chứng không có florfenicol. Sau đó các thức ăn được bổ sung 1\% Carboxy Methyl Cellulose (chất kết dính), tái ép viên với đường kính $1 \mathrm{~mm}$, sấy ở nhiệt độ $50^{\circ} \mathrm{C}$ trong 6 giờ và bảo quản ở tủ đông $-20^{\circ} \mathrm{C}$ cho đến khi sử dụng.

Thí nghiệm được bố trí theo phương pháp hoàn toàn ngẫu nhiên với 4 nghiệm thức (NT) gồm đối chứng âm $\mathrm{ĐC}(-)$, đối chứng dương $\mathrm{ĐC}(+)$ được cho ăn thức ăn không có florfenicol; và $\mathrm{NT} 10$ và NT15 được cho ăn thức ăn có hàm lượng florfenicol lần lượt là 500 và $750 \mathrm{mg} / \mathrm{kg}$ tương ứng với liều florfenicol kiểm soát bệnh là 10 và $15 \mathrm{mg} / \mathrm{kg}$ thể trọng cá. Mỗi NT có 5 lần lặp lại với 20 cá/lần lặp lại. Từ ngày 1 đến ngày 10 sau khi gây nhiễm, cá ở NT ĐC(-) và ĐC(+) được cho ăn thức ăn không có florfenicol, cá ở NT10 và NT15 được cho ăn thức ăn có florfenicol. Từ ngày 11 đến ngày 24 , cá trong tất cả các nghiệm thức được cho ăn thức ăn không có florfenicol. Lượng thức ăn cho cá ăn trong ngày tương ứng $4 \%$ trọng lượng thân.

\subsection{Kiểm tra hàm lượng và dư lượng của flor- fenicol trong thức ăn và cơ thịt cá}

Thức ăn sử dụng cho cá ở các nghiệm thức của thí nghiệm sử dụng florfenicol kiểm soát bệnh được gửi mẫu xét nghiệm hàm lượng florfenicol tại Trung Tâm Dịch Vụ Phân Tích Thí Nghiệm thành phố Hồ Chí Minh.

Cá thí nghiệm của các nghiệm thức NT10 và NT15 được thu mẫu kiểm tra dư lượng florfenicol trong cơ thịt vào các ngày $1,16,20$ và 24 sau khi ngưng sử dụng thức ăn có florfenicol (tương ứng với các ngày $11,26,30$ và 34 sau khi gây nhiễm với F. columnare). Mỗi thời điểm thu 1 cá/nghiệm thức. Số cá thu vào ngày 11 sau gây nhiễm không được tính vào tỷ lệ cá chết của các nghiệm thức. Cá được gây mê trong nước pha thuốc gây mê AQUIS $^{\circledR}$ (Bayer) 10 ppm, sau đó được đánh vảy, lóc lườn thịt hai bên cơ thể cho vào túi nhựa riêng và bảo quản ở $-20^{0} \mathrm{C}$ cho đến khi được gửi mẫu phân tích.

\subsection{Phân tích thống kê}

Tỷ lệ cá chết (\%) được chuyển đổi sang giá trị arcsin căn bậc hai của tỷ lệ chết, sau đó thiết lập bảng ANOVA xác định sự khác biệt giữa 
các nghiệm thức và phân tích sự khác biệt giữa các nghiệm thức ở xác suất $P<0,05$ bằng trắc nghiệm Duncan với phần mềm SPSS 16.0.

\section{Kết Quả và Thảo Luận}

\subsection{Kiểm tra sức khỏe cá trước khi cảm nhiễm và chất lượng nước trong bể cá}

Trước khi gây nhiễm, cá được kiểm tra tình trạng nhiễm ký sinh trùng trên mang và da cũng như tình trạng nhiễm khuẩn trong nội quan gan, thận và lách. Kết quả kiểm tra cho thấy không phát hiện sự hiện diện của ký sinh trùng từ các mẫu nhớt, da và mang của cá được kiểm tra. Kết quả kiểm tra nhiễm khuẩn cũng cho thây không phát hiện sự hiện diện của bất kỳ khuẩn lạc vi khuẩn từ các mẫu cấy gan, thận và lách của cá kiểm tra.

Các chỉ tiêu chất lượng nước trong bể của cả hai thí nghiệm xác định $\mathrm{LD}_{50}$ và kiểm soát tỷ lệ chết của cá do $F$. columnare ghi nhận được đều dao động trong khoảng giới hạn thích hợp cho sự sống và phát triển bình thường của cá rô phi. Do nhiệt độ phòng thí nghiệm gây bệnh được ổn định bởi máy điều hòa nhiệt độ nên nhiệt độ nước trong bể duy trì trong khoảng $25-28^{\circ} \mathrm{C}$. Đây là khoảng nhiệt độ thích hợp cho $F$. columnare gây bệnh trên cá (Robert \& ctv., 1998). Nước trong bể được sục khí liên tục nên DO luôn duy trì ở mức $5-7 \mathrm{mg} / \mathrm{L}$. Thêm vào đó, các bể được thay $20-30 \%$ lượng nước mỗi ngày nên $\mathrm{pH}$ ít biến động $(6,5-7,5)$ và $\mathrm{NH}_{3}$ ở nồng độ rất thấp (0,0001 - 0,0005 mg/L).

Kết quả kiểm tra kháng sinh đồ cho thấy chủng $F$. columnare T3-8/10 nhạy hoàn toàn với 6 loại kháng sinh kiểm tra, trong đó đường kính vòng vô khuẩn tại đĩa florfenicol lên đến $52 \mathrm{~mm}$ (Bảng 2). Theo Tu \& ctv. (2012), các chủng $F$. columnare phân lập từ cá tra có tỷ lệ $85 \%$ nhạy với ampicillin và tetracyclin và $30 \%$ nhạy với Trimethoprime/Sulfamethoxazol. Rahman \& ctv. (2010) báo cáo các chủng $F$. columnare phân lập từ cá rô đồng nhạy cảm với chloramphenicol, oxytetracycline, erythromycin và streptomycin. Trong nghiên cứu này, chủng $F$. columnare T3-8/10 vẫn còn nhạy cảm với nhiều loại kháng sinh. Florfenicol cho vòng vô khuẩn có đường kính lớn nhất nên kháng sinh này được ưu tiên được chọn sử dụng trong kiểm soát bệnh thối đuôi, mòn vây do $F$. columnare trên cá rô phi.

\subsection{Liều $\mathrm{LD}_{50}$ của chủng Flavobacterium columnare T3-8/10}

\subsubsection{Phân lập và định danh $F$. columnare}

Cá bệnh được thu mẫu, soi tươi và nhuộm Gram mẫu nhớt tại các vị trí loét da và mòn vây dưới kính hiển vi. Rất nhiều vi khuẩn dạng sợi, mảnh, kích thước khoảng $10-20 \mu \mathrm{m}$ và di động mạnh có thể quan sát được trong mẫu soi tươi nhớt da. Các vi khuẩn dạng sợi mảnh này bắt màu Gram âm khi được nhuộm Gram (Hình 1). Đây chính là hình thái đặc trưng của vi khuẩn dạng sợi $F$. columnare đã được báo cáo phân lập từ cá rô phi (Oreochromis niloticus) (Figueido \& ctv., 2005) và cá rô đồng (Anabas testudenius) (Rahman \& ctv., 2010).

Khi cấy phân lập các mẫu nhớt trên môi trường chọn lọc Cytophaga agar có bổ sung kháng sinh neomycin và polymycin, các khuẩn lạc có màu vàng nhạt, rìa dạng rễ cây bám chặt vào bề mặt thạch xuất hiện rõ sau khi ủ ở $28^{0} \mathrm{C}, 72$ giờ (Hình 2). Từ các mẫu cấy phân lập, vi khuẩn đã được phân lập thuần trên môi trường Cytophaga được kiểm tra bằng phản ứng $\mathrm{PCR}$ với cặp mồi đặc hiệu $\mathrm{FcFd} / \mathrm{FcRs}$. Tất cả vi khuẩn phân lập đều cho băng DNA có kích thước khoảng 504 bp trên bảng điện di (Hình 3).

\subsubsection{Kết quả gây nhiễm và xác định ${ }^{2} D_{50}$}

Kết quả kiểm tra mật độ $F$. columnare trong môi trường tăng sinh điều chỉnh về $\mathrm{OD} 0,2$ bằng phương pháp cấy trang trên Cytophaga agar đạt $8,7 \times 10^{8} \mathrm{CFU} / \mathrm{mL}$. Như vậy, liều gây nhiễm của các nghiệm thức $\mathrm{T} 1, \mathrm{~T} 2$, T3 và $\mathrm{T} 4$ lần lượt là $8,7 \times 10^{3}, 8,7 \times 10^{4}, 8,7 \times 10^{5}$ và $8,7 \times 10^{6}$ $\mathrm{CFU} / \mathrm{mL}$.

Ngày đầu tiên sau gây nhiễm cá vẫn có biểu hiện bình thường. Tuy nhiên, sang ngày thứ hai cá có biểu hiện lờ đờ và giảm bắt mồi. Cá chết từ ngày thứ 2 trở đi và số lượng chết tăng dần cho đến ngày thứ 12 sau gây nhiễm. Liều gây nhiễm cao hơn cho số lượng cá chết nhiều hơn. Cá bệnh nhẹ trên da và vây tiết nhiều nhớt. Cá bệnh nặng có vùng da hai bên thân bị lở loét và vây tưa rách, cụt, đặc biệt là vây đuôi (Hình 4).

Số lượng và tỷ lệ cá chết trung bình của các nghiệm thức trong thí nghiệm xác định $\mathrm{LD}_{50}$ được trình bày ở Bảng 3 . Tỷ lệ cá chết cộng dồn nhỏ hơn $50 \%$ và lớn hơn $50 \%$ số cá thí nghiệm thuộc các nghiệm thức $\mathrm{T} 1$ và $\mathrm{T} 2$ với mật độ vi khuẩn gây nhiễm lần lượt là $8,7 \times 10^{3}$ và 8,7 
Bảng 1. Bố trí thí nghiệm kiểm soát bệnh do F. columnare bằng florfenicol

\begin{tabular}{|c|c|c|c|c|}
\hline Nghiệm thức & $\begin{array}{l}\text { Liều florfenicol } \\
\text { (mg/kg cá) }\end{array}$ & Gây nhiễm & Cho ăn từ ngày 1 -10 & Cho ăn từ ngày $11-24$ \\
\hline ĐC (-) & (2) & Không & $\begin{array}{c}\text { Thức ăn } \\
\text { không có florfenicol }\end{array}$ & $\begin{array}{c}\text { Thức ăn } \\
\text { không có florfenicol }\end{array}$ \\
\hline ĐC $(+)$ & 0 & Có & $\begin{array}{l}\text { Thức ăn } \\
\text { không có florfenicol }\end{array}$ & $\begin{array}{l}\text { Thức ăn } \\
\text { không có florfenicol }\end{array}$ \\
\hline NT10 & 10 & Có & $\begin{array}{l}\text { Thức ăn } \\
\text { có florfenicol }\end{array}$ & $\begin{array}{l}\text { Thức ăn } \\
\text { không có florfenicol }\end{array}$ \\
\hline NT15 & 15 & Có & $\begin{array}{l}\text { Thức ăn } \\
\text { có florfenicol }\end{array}$ & $\begin{array}{l}\text { Thức ăn } \\
\text { không có florfenicol }\end{array}$ \\
\hline
\end{tabular}

Bảng 2. Đường kính vòng vô khuẩn $(\mathrm{mm})$ của chủng $F$. columnare T3-8/10

\begin{tabular}{ccccc}
\hline Kháng sinh & Hàm lượng $(\mu \mathrm{g})$ & Nhạy & Kháng & T3-8/10 \\
\hline Ampicillin & 10 & $>17$ & $<13$ & 32 \\
Doxycycline & 30 & $>16$ & $<12$ & 32 \\
Florfenicol & 30 & $>19$ & $<14$ & 52 \\
Gentamycin & 10 & $>15$ & $<12$ & 28 \\
Tetracycline & 30 & $>19$ & $<14$ & 40 \\
Trimethoprim/sulfamethoxazole & $1,25 / 23,75$ & $>16$ & $<10$ & 26 \\
\hline
\end{tabular}
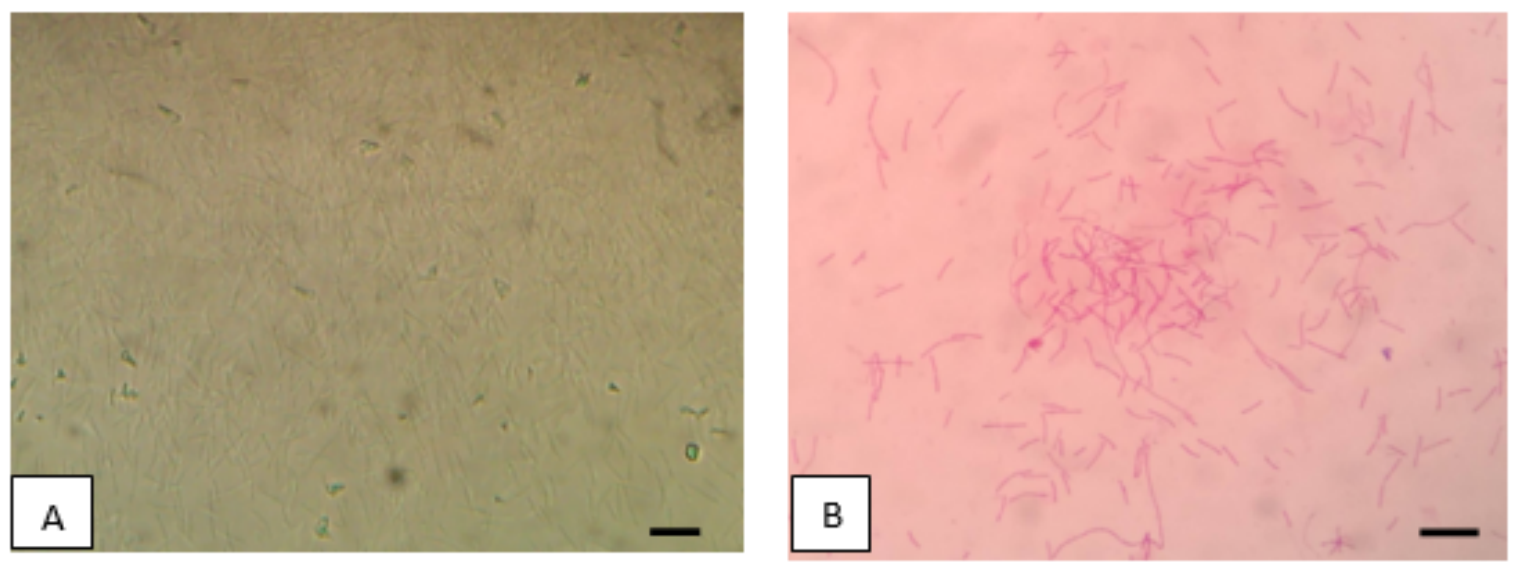

Hình 1. Hình thái Flavobacterium columnare. Soi tươi (A) và nhuộm Gram (B), (kích thước thanh: $10 \mu \mathrm{m})$.

$\times 10^{4} \mathrm{CFU} / \mathrm{mL}$. Kết quả tính toán liều $\mathrm{LD}_{50}$ của chủng $F$. columnare T3-8/10 theo phương pháp của Reed \& Muench (1938) đạt 4,8 × $10^{4}$ $\mathrm{CFU} / \mathrm{mL}$.

Flavobacterium columnare là vi khuẩn hiện diện trong hầu hết môi trường nuôi thủy sản. Vi khuẩn này được xem là mầm bệnh cơ hội khi cá bị stress do chất lượng môi trường nuôi kém như oxy hòa tan thấp, nồng độ ammonia, nitrite tăng cao hay cá bị xay sát do cơ học như vận chuyển, đánh bắt (Robert \& ctv., 1998). Do đó trong các thí nghiệm gây cảm nhiễm với mầm bệnh cơ hội, liều gây bệnh cần phải khá lớn để gây nhiễm thành công. Các kết quả nghiên cứu đã được công bố cho thấy liều $\mathrm{LD}_{50}$ khi gây bệnh bằng phương pháp ngâm cho cá tra (Pangasianodon hypophthalmus) là $3,2 \times 10^{6} \mathrm{CFU} / \mathrm{mL}(\mathrm{Tu}$ \& ctv. 2012). Rahman \& ctv. (2010) đã gây nhiễm cá rô đồng bằng phương pháp ngâm ở mật độ 3 $-5 \times 10^{8} \mathrm{CFU} / \mathrm{mL}$ với các chủng $F$. columnare khác nhau và đã ghi nhận tỷ lệ cá chết thay đổi từ $40-100 \%$. Tuy nhiên, Figueido \& ctv. (2005) đã không thành khi gây nhiễm cá da trơn Mỹ (Ictalurus punctatus) bằng phương pháp ngâm với 
Bảng 3. Số lượng và tỷ lệ cá chết trung bình trong thí nghiệm xác định $\mathrm{LD}_{50}$

\begin{tabular}{cccccc}
\hline Nghiệm thức & Lặp lại & Số cá bố trí/lần lặp lại & $\begin{array}{c}\text { Số cá chết } \\
\text { cộng dồn }\end{array}$ & $\begin{array}{c}\text { Số cá sống } \\
\text { cộng dồn }\end{array}$ & $\begin{array}{c}\text { Tỷ lệ chết } \\
\text { cộng dồn }(\%)\end{array}$ \\
\hline T1 & 2 & 20 & 9 & 25,5 & 26,1 \\
T2 & 2 & 20 & 21,5 & 14,5 & 82,7 \\
T3 & 2 & 20 & 36.5 & 7 & 83,9 \\
T4 & 2 & 20 & 54,5 & 2 & 96,5 \\
\hline
\end{tabular}

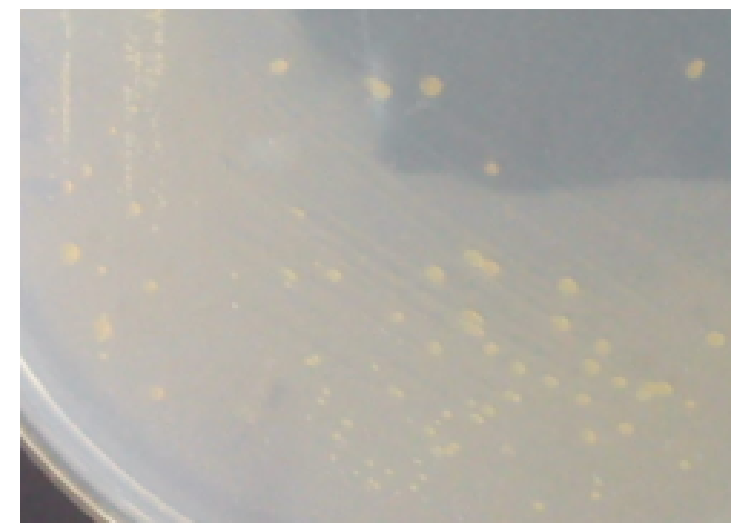

Hình 2. Phân lập Flavobacterium columnare từ cá rô phi. Khuẩn lạc từ mẫu cấy vết loét da cá rô phi có màu vàng nhạt, dạng rễ cây trên môi trường thạch Cytopha bổ sung polymyxin và neomycin sau 72 giờ ủ ở $28^{0} \mathrm{C}$.

mật độ vi khuẩn gây nhiễm $3,0 \times 10^{7} \mathrm{CFU} / \mathrm{mL}$. Trong thí nghiệm này cá được gây nhiễm bằng phương pháp tắm với thời gian tiếp xúc giữa cá và chủng $F$. columnare T3-8/10 không giới hạn với kết quả $\mathrm{LD}_{50}$ đạt $4,8 \times 10^{4} \mathrm{CFU} / \mathrm{mL}$ và thấp hơn so với nghiên cứu trước đây. So với phương pháp ngâm, phương pháp tắm hoàn toàn không gây stress cho cá vì không cần chuyển cá sang bể ngâm vi khuẩn. Cá không bị stress nên không ảnh hưởng đến mức độ bắt mồi là thức ăn có florfenicol trong thí nghiệm kiểm soát bệnh.

\subsection{Kiểm soát bệnh do $F$. columnare}

\subsubsection{Lượng thức ăn cá tiêu thụ}

Bảng 4 trình bày lượng thức ăn cá ăn ở các nghiệm thức. Kết quả cho thấy cá ở nghiệm thức ĐC(-) tiêu thụ thức ăn nhiều nhất và thấp nhất là cá ở $\mathrm{DC}(+)$. Cá ở NT10 và NT15 có lượng tiêu thụ thức ăn thấp hơn ĐC(-) tuy nhiên sự khác biệt này là không đáng kể. Kết quả này cho thấy hàm lượng 500 và $750 \mathrm{mg} / \mathrm{kg}$ florfenicol trong thức ăn không ảnh hưởng đến mức độ bắt mồi của cá rô phi.

\subsubsection{Hàm lượng florfenicol trong thức ăn}

Kết quả kiểm tra hàm lượng florfenicol trong thức ăn của các nghiệm thức NT10 và NT15 lần lượt là 407,6 và $678,2 \mathrm{mg} / \mathrm{kg}$. So với dự định hàm lượng florfenicol 500 và $750 \mathrm{mg} / \mathrm{kg}$ thức ăn, hàm lượng florfenicol thực tế có trong thức ăn sử dụng cho cá ở NT10 và NT15 thấp hơn. Trong thí nghiệm này, cá có trọng lượng trung bình khoảng $20 \mathrm{~g} /$ cá. Lượng florfenicol một cá thể cá trong $\mathrm{NT} 10$ và NT15 cần tiêu thụ lần lượt 0,2 và 0,3 $\mathrm{mg} /$ ngày nhằm đạt được liều chỉ định florfenicol 10 và $15 \mathrm{mg} / \mathrm{kg}$ cá/ngày. Từ kết quả trình bày ở bảng 7 , một cá thể cá trong NT10 và NT15 ăn lượng thức ăn lần lượt 0,75 và $0,76 \mathrm{~g} /$ ngày. Như vậy, lượng florfenicol một cá thể cá trong nghiệm thức NT10 và NT15 tiêu thụ lần lượt là 0,54 và $0,89 \mathrm{mg} / \mathrm{ngày}$. Roiha và ctv. (2011) đã áp dụng liều chỉ định florfenicol $10 \mathrm{mg} / \mathrm{kg}$ cá/ngày trong điều trị nhiễm khuẩn $F$. columnare trên ấu trùng cá halibut (Hippoglossus hippoglossus). Tuy nhiên, lượng florohenicol thực tiễn ấu trùng cá trong các nghiệm thức tiêu thụ lên đến 30 $115 \mathrm{mg} / \mathrm{kg}$ cá/ngày. Các kết quả trên cho thấy việc cấp thuốc cho cá theo đúng liều chỉ định có phần khó khăn hơn so với động vật trên cạn. Tuy nhiên, đặc biệt đối với kháng sinh, lượng kháng sinh cá tiêu thụ được thực tế khó có thể đúng nhưng cần cao hơn liều chỉ định nhằm đạt hiệu quả điều trị cao và hạn chế tình trạng vi khuẩn trở nên đề kháng kháng sinh.

\subsubsection{Tỷ lệ cá chết ở các nghiệm thức}

Cá được gây nhiễm bằng phương pháp tắm với liều $F$. columnare $6,9 \times 104 \mathrm{CFU} / \mathrm{mL}$ (xấp xỉ với liều $\mathrm{LD}_{50} 4,8 \pm 104 \mathrm{CFU} / \mathrm{mL}$ ). Sau 14 ngày gây bệnh, cá ở các bể đối chứng âm vẫn bơi lội linh hoạt, phản ứng nhanh nhẹn với tiếng động. Trên cơ thể cá không thấy xuất hiện bất cứ dấu hiệu nhiễm bệnh nào. Điều này chứng tỏ cá ở nghiệm thức ĐC(-) vẫn hoàn toàn khỏe mạnh. Ở 


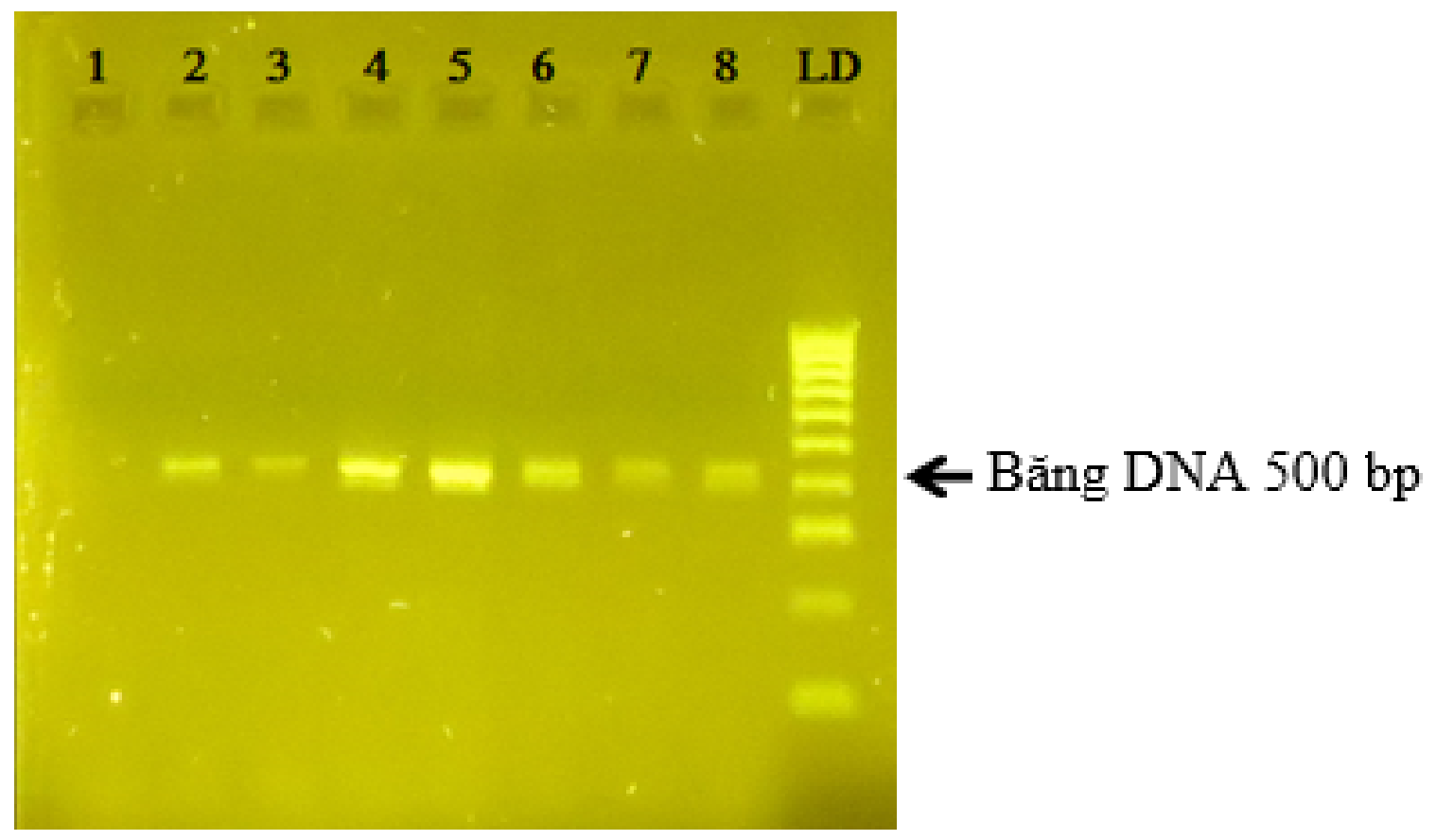

Hình 3. Ảnh điện di sản phẩm PCR phát hiện Flavobacterium columnare của các gốc vi khuẩn phân lập từ cá rô phi (băng DNA đặc hiệu 504 bp).

Giếng 1: Đối chứng (-). Giếng 2 - 4: Các gốc vi khuẩn phân lập từ cá bệnh của thí nghiệm $\mathrm{LD}_{50}$.

Giếng 5: Chủng F. columnare T3-8/10. Giếng 6-8: Các gốc vi khuẩn phân lập từ cá bệnh của thí nghiệm kiểm soát tỷ lệ cá chết do F. columnare bằng florfenicol. Giếng LD: Thang DNA 100 bp.

Bảng 4. Lượng thức cá ăn trong 10 ngày thí nghiệm kiểm soát bệnh

\begin{tabular}{cccc}
\hline NT & Số lượng cá & Tổng lượng thức ăn $(\mathrm{g})$ & Lượng thức ăn $(\mathrm{g})$ một cá thể cá ăn/ngày \\
\hline ĐC $(-)$ & 100 & 777,4 & 0,78 \\
ĐC $(+)$ & 100 & 602,2 & 0,60 \\
NT 10 & 100 & 749,0 & 0,75 \\
NT 15 & 100 & 763,0 & 0,76 \\
\hline
\end{tabular}

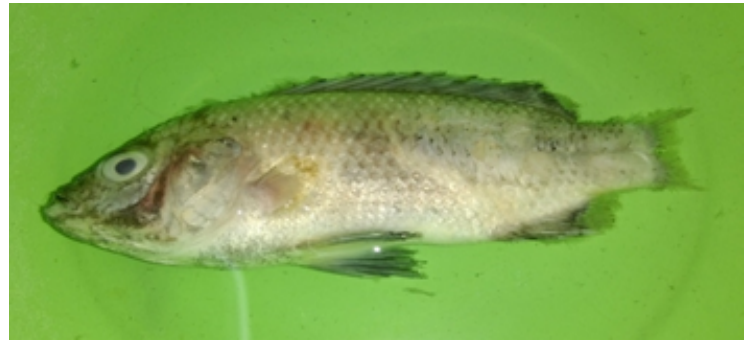

Hình 4. Biểu hiện bên ngoài của cá bệnh trong thí nghiệm $\mathrm{LD}_{50}$.

các nghiệm thức gây nhiễm, từ ngày thứ 2 cá bắt đầu chết ở $\mathrm{DC}(+)$ và $\mathrm{NT} 10$. Trong khi đó cá ở NT15 chỉ bắt đầu chết từ ngày thứ 3 . Cá ở ĐC $(+)$ có tỷ lệ chết tăng liên tục đến ngày thứ 13. Các nghiệm thức sử dụng florfenicol hoàn toàn không còn cá chết sau ngày thứ 3 ở NT10 và ngày thứ 6 ở NT15 (Hình 5). Tỷ lệ cá chết sau 14 ngày gây nhiễm ở $\mathrm{ĐC}(+)$ lên đến $54.0 \pm 5.47 \%$ và khác biệt có ý nghĩa thống kê $(P<0,05)$ so với tỷ lệ chết ở ĐC(-), NT10 và NT15 lần lượt là 0,$0 ; 3,0$ $\pm 4,72$ và $2,60 \pm 2,51 \%$. Tỷ lệ cá chết ở nghiệm thức NT10 và NT15 khác biệt không có ý nghĩa thống kê so với ở ĐC(-) $(P>0,05)$.

Tất cả cá chết đều xuất hiện các biểu hiện vệt trắng ở đuôi, hai bên thân và mất nhiều nhớt. Vùng da bị nhiễm khuẩn mất đi màu sáng tự nhiên, ở mép vết thương có màu xám, trắng bao quanh. Các vây, đặc biệt là vây đuôi, bị mòn và 


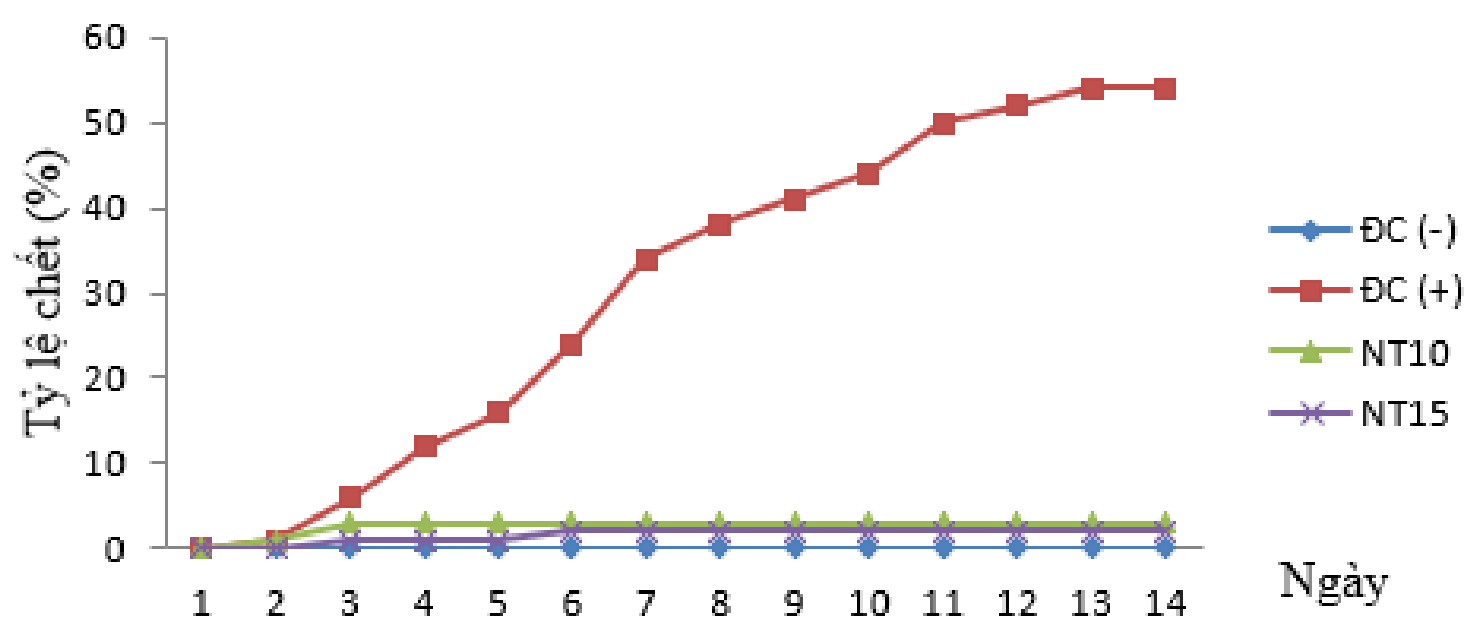

Hình 5. Tỷ lệ cá chết (\%) trong thí nghiệm kiểm soát cảm nhiễm $F$. columnare bằng florfenicol.

cụt dần. Kết quả phân lập và định danh vi khuẩn bằng kỹ thuật $\mathrm{PCR}$ cho thấy $F$. columnare là tác nhân duy nhất gây bệnh này trên cá rô phi trong quá trình tiến hành thí nghiệm trị bệnh.

Florfenicol là kháng sinh đã được sử dụng với liều 10 và $15 \mathrm{mg} / \mathrm{kg}$ cá với liệu trình 10 ngày liên tục nhằm kiểm soát nhiều bệnh nhiễm khuẩn trên nhiều loài cá khác nhau như Francisella asiatica trên cá rô phi (Esteban \& ctv., 2010), F. columnare trên ấu trùng cá halibut (Hippoglossus hippoglossus) (Roiha \& ctv., 2011), F. columnare trên cá sunshine bass (cá mẹ Morone chrysops lai cá bố Morone saxatilis) (Darwish \& ctv., 2012) và Edwardsiella ictaluri trên loài cá da trơn Mỹ (Ictalurus punctatus) (Patricia \& ctv., 2006). Darwish \& ctv. (2012) báo cáo kết quả sử dụng florfenicol liều $15 \mathrm{mg} / \mathrm{kg}$ thể trọng cá trong liệu trình 10 ngày điều trị nhiễm khuẩn tự nhiên $F$. columnare trên cá sunshine bass đã nâng cao tỷ lệ sống lên $90 \%$ so với cá không được điều trị là $71 \%$. Roiha \& ctv. (2011) với liều và liệu trình điều trị như trên đã thành công trong điều trị nhiễm $F$. columnare trên ấu trùng cá halibut (Hippoglossus hippoglossus). Kết quả cho thấy toàn bộ âu trùng trong các bể không được điều trị chết trong vòng 6 ngày sau khi có biểu hiện bệnh. Trong khi đó, ấu trùng ở các bể điều trị sau 2 ngày đã giảm đáng kể tỷ lệ chết và sau 6 ngày cá bình phục hoàn toàn. Tỷ lệ chết của ấu trùng ở cá bể này chỉ ở mức $32 \%$.

\subsubsection{Dư lượng florfenicol trong cơ thịt cá}

Kết quả kiểm tra dư lượng florfenicol trong cơ thịt cá được trình bày ở Bảng 5 . Thời gian ngưng sử dụng một loại kháng sinh trước khi thu hoạch cá nếu không được quy định cư thể có thể áp dụng theo mức 500 dộ ngày. Độ là nhiệt độ trung bình của môi trường nước trong thời gian ngưng kháng sinh (Edward, 2000). Nhiệt độ nước trong các bể thí nghiệm kiểm soát bệnh biến động trong khoảng $25-28^{\circ} \mathrm{C}$. Như vậy thời gian cần thiết để cơ thể cá loại thải florfenicol tính theo nhiệt độ cao nhất và thấp nhất của nước trong bể là 18 đến 20 ngày. Kết quả kiểm tra dư lượng kháng sinh florfenicol trong cơ thịt cá giảm dần theo thời điểm thu mẫu kiểm tra (Bảng 5 ) và đều thấp hơn mức 1000 ppb theo thông tư số 15/2009/TTBNN ban hành ngày 17 tháng 3 năm 2009 của Bộ trưởng Bộ Nông Nghiệp và Phát Triển Nông Thôn.

Bảng 5. Dư lượng florfenicol trong cơ thịt cá sau khi ngưng cho ăn kháng sinh (ppb)

\begin{tabular}{ccc}
\hline Ngày & NT10 & NT15 \\
\hline 1 & 10,0 & 50,2 \\
16 & 3,8 & 3,8 \\
20 & 2,0 & 2,5 \\
24 & 1,2 & 2,1 \\
\hline
\end{tabular}




\section{Kết Luận và Đề Nghị}

\subsection{Kết luận}

Cho cá ăn cho ăn thức ăn có florfenicol với hàm lượng 407,6 và $678,2 \mathrm{mg} / \mathrm{kg}$ thức ăn với tỷ lệ $4 \% /$ ngày dều có hiệu quả kiểm soát tốt tỷ lệ chết trên cá rô phi trong điều kiện gây bệnh thực nghiệm với chủng Flavobacterium columnare T3$8 / 10$.

Florfenicol có thể sử dụng một cách an toàn với dư lượng trong cơ thịt cá thí nghiệm thấp hơn mức giới hạn quy định.

\section{2. Đề nghị}

Thử nghiệm kiểm soát bệnh do $F$. columnare trên cá rô phi trong ao ương và bè nuôi.

\section{Tài Liệu Tham Khảo (References)}

Darwish, M. A., Bebak, J. A., \& Schrader, K. K. (2012). Assessment of Aquaflo ${ }^{\circledR}$, copper sulphate and potassium permanganate for control of Aeromonas hydrophila and Flavobacterium columnare infection in sunshine bass, Morone chrysops female x Morone saxatilis male. Journal of Fish Diseases 35(9), 637-647.

Edward, J. N. (2000). Fish disease diagnosis and treatment ( $2^{\text {th }}$ ed., 272-273). Iowa, USA: Wiley and Blackwell.

Figueido, H. C. P., Klesius, P. H., Arias, C. R., Evans, J., Shoemaker, C. A., \& Pereira, D. J. (2005). Isolation and characterization of strains of Flavobacterium columnare from Brazil. Journal of Fish Diseases 28(4), 199-204.

Esteban S., Richard G. E., \& John P. H. (2010). In vitro and in vivo efficacy of florfenicol for treatment of Francisella asiatica infection in tilapia. Antimicrobial Agents and Chemotherapy 54 (11), 4664-4670.

Gaunt, P. S., Gao, D., Sun, F., \& Endris, R. (2010). Efficacy of florfenicol for control of mortality caused by Flavobacterium columnare infection in Channel Cat fish. Journal of Aquatic Animal Health 22(2),115-122.
McGinnis, A., Gaunt, P., Santucci, T., Simmons, R., \& Endris, R. (2003). In vitro evaluation of the susceptibility of Edwardsiella ictaluri, etiological agent of enteric septicemia in Channel Catfish, Ictalurus punctatus (Rafinesque), to florfenicol. Journal of Veterinary Diagnostic Investigation 15(6), 576-579.

NCCLS (National Committee for Clinical Laboratory Standard of Antimicrobial Susceptibility). (2001). Testing; Eleventh Information Supplement. Pennsylvania, USA: NCLS document M100-S11 NCCLS.

Panangala, V. S., Shoemaker, C. A., Van Santen, V. L., Dybvig, K., \& Klesius, P. H. (2007). Multiplex-PCR for simultaneous detection of 3 bacterial fish pathogens, Flavobacterium columnare, Edwardsiella ictaluri, and Aeromonas hydrophila. Diseases of Aquatic Organism 74(3), 199-208.

Patricia, S. G., Anissa. L. M., Timothy, D. S., Jean, C., \& Peter, W. (2006). Field Efficacy of Florfenicol for Control of Mortality in Channel Catfish, Ictalurus punctatus (Rafinesque), Caused by Infection with Edwardsiella ictaluri. Journal of The World Aquaculture Society 37(1), 1-11.

Rahman, M. M., Ferdowsy, H., Kashem, M. A., \& Foysal, M. J. (2010). Tail and Fin Rot Disease of Indian Major Carp and Climbing Perch in Bangladesh. Journal of Biological Sciences 10(8), 800-804.

Reed, L.J., \& Muench, H. (1938). A simple method of estimating fifty percent endpoints. The American Journal of Hygiene 27, 493-497.

Robert, M. D., Ronald, L. T., John, P. H., \& Camus, A. C. (1998). Columnaris disease: A bacterial infection caused by Flavobacterium columnare. Southern Regional Aquaculture Center Publication 479, 31-44.

Roiha, I. S., Samuelsen, O. B., \& Harboe, T. (2011). Efficacy of florfenicol in the treatment of bacterial infections in halibut, Hippoglossus hippoglossus (L.), larvae. Journal of Fish Diseases 34(12), 927-930.

Tu, D. T., Nguyen, T. T., \& Nguyen, T. A. (2012). Study the aetiological agent causing white patch disease in catfish farm (Pangasianodon hypophthalmus) and therapy solution. Can Tho University Journal of Science 22c, 136-145. 